\title{
漸拡水路における表層流の流動特性と フェンスエの設置効果
}

\author{
SURFACE CURRENTS IN A DIVERGING CHANNEL AND IT'S CONTROL BY \\ CURTAINS FOR COUNTERING FRESH WATER RED-TIDE BLOOMS
}

\author{
秋山壽一郎 ${ }^{1} \cdot$ 片山 哲幸 ${ }^{2} \cdot$ 山崎 勉 $^{2} \cdot$ 浦 勝 $^{3}$ \\ Juichiro AKIYAMA, Tetuyuki KATAYAMA, Tutomu YAMASAKI and Masaru URA \\ ${ }^{1}$ 正会員 Ph. D 九州工業大学教授 工学部建設社会工学科 (广 804-8550 北九州市戸畑区仙水町 1-1) \\ 2 学生員 九州工業大学大学院 工学研究科博士前期課程 (同上) \\ ${ }^{3}$ 正会員 工博 九州工業大学教授 工学部建設社会工学科（同上）
}

\begin{abstract}
Some of such missing information on the front of surface currents spreading in a diverging channel as intrusion length, flow thickness and densimetric Froude number in both buoyancy-inertia and buoyancyviscous region have been quantified experimentally.

The effects of a curtain, placed in the steady surface currents in a diverging channel, on the mixing of lighter inflow water with heavier ambient water are investigated experimentally. It is found that some of heavier ambient water is lifted up by the upwelling motion of the lighter surface layer fluid along the curtain, and consequently the dilution rate of surface layer will increase with the ratio of the submerged depth of the curtain to the inflow depth.
\end{abstract}

Key Words: surface current, reservoir, diverging channel curtain, algal blooming

\section{1.はじめに}

ダム貯水池の水循環や水質は流入河川水の性質に 大きく左右される。これは、そこでの成層の状態や 流入河川水との密度差の程度によって、流入水が表 層流、下層流あるいは中層流などの流入型密度流と して池内を流動するためである。場所にもよるが、 早春から 6 月初旬にかけては流入水の水温が貯水池 水温より高くなることがあり、この時期に貯水池上 流端で発生した淡水赤潮が表層流に乗り水域全体に 拡がることがある11。

富栄養化現象に対する池内対策として流動制御が あるが、その中でも污濁拡散防止幕を水面から垂ら したフェンスエは比較的安価であり、その効果に関 する検討が試験的に実施されている゙,3)。フェンス 工（以下では、簡単のため幕と呼ぶ）は、貯水池を 横断するように設置することで、植物プランクトン の水域への拡散を防止するとともに、その異常増殖 の主要な要因である栄養塩類の制御と光合成反応に 必要な光や水温などの環境条件の人為的な操作を図 ろうとするものであるが、表層流の流動特性が充分 に解明されていないこともあって、その設置を行う 際の設置深さや幕が設置された場合の表層流の希釈
混合効果などについて充分な知見が得られているわ けではない。

密度噴流のように流出時に浮力に比して慣性力が 比較的強い表層流については、発電所からの温排水 や河口部での河川流出などを対象として、これまで 膨大な量の研究がなされている ${ }^{4 \sim 9)}$ 。また、浮力に 比して慣性力が弱い場合の表層流としては流出油の 拡がりの問題があり、これについても表面張力の効 果も含めて活発な研究がなされている ${ }^{10,11)}$ 。

貯水池等への河川水の流入によって発生する表層 流のように、表面張力が問題とならない表層流のフ ロント特性は、慣性力、浮力および粘性力の 3 者の 大小関係で決定され、浮力と慣性力がバランスする 浮力ー慣性力領域がまず表れ、次いで浮力と粘性力 がバランス寸る浮力ー粘性力領域となり、浮力慣性 力領域から浮力-粘性力領域に遷移する遷移領域で は 3 力がバランスすることが、これまでの研究で明 らかにされているが10,12)、定量的な関係が示されて いないので、著者ら ${ }^{13)}$ は上下層が明確な界面を有す る場合の浮力-慣性力領域と浮力-粘性力領域におけ る 1 次元表層流のフロント特性を定量的に明らかに した。

本研究は、ダム貯水池のように下流に向かって水 
路幅が漸拡するような水域での 2 次元表層流のフロ ント特性および表層流中に幕を設置した場合の希釈 混合効果について実験的に検討を加えたものである。 なお、研究の結果より、幕の設置は火力発電所から の温排水の希釈にも有効に作用すると考えられる。

\section{2. 実験}

実験装置は、図-1に示すように、水深 $h=50 \mathrm{~cm}$ での 塩水 $\left(\right.$ 密度 $\rho_{\mathrm{a}}$ )を満たした全面アクリル製の水槽 (長 さ $5.0 \mathrm{~m} 、$ 幅 $0.2 \mathrm{~m}$ 、高さ $0.6 \mathrm{~m})$ 中に水路幅 $\mathrm{B}_{0}$ 、水深 $\mathrm{a}$ の 流入部とその下流側に片側の側璧の拡がり角度 $\alpha$ が 一定 $\left(1.24^{\circ}\right)$ )漸拡水路を設置したものであり、水 槽下流端には貯留水水深を一定に保つ目的で、越流 堰が設けられている。流入部前面には開放ゲートが 設置されており、流入部内部の水位が水槽内に貯留 された塩水の水位と一致した瞬間に開放ゲートを引 き上げ、ウラニンで着色した淡水 $\left(\rho_{0}\right)$ を一定流入流 量 $\mathrm{Q}_{0}$ で貯留塩水中に放出し表層流を発生させた。流 入部の内部には、流入水深と同じ高さaで越流堰が 設置されており、一定流量 $Q_{i}$ でヘッドタンクから流 入部に供給された淡水の一部は、一定流量 $Q_{\mathrm{e}}$ で越流 堰の左側に流出し、流入流量 $\mathrm{Q}_{0}$ を一定に保つように なっている。これは、流入に際して余剩あるいは不 足のflow forceが働かないようにするための工夫で あり、 $Q_{0}=Q_{i}-Q_{e} よ り$ 流入流量を算定している。ただ し、より正確にQ $Q_{0}$ を算定するために、各流入条件に ついて予備実験を行い、堰からの越流水深がほぼ 0 となるような $Q_{i}$ を決定した後に、本実験を実施した。 このような慎重な配慮は、表層流フロントの流動特 性が流入条件によって容易に変化することを踏まえ にものである。図ー1中には対象とする現象に関連す る重要な諸量も示されている。

実験内容としては、幕が設置されていない状況で の表層流フロントの流動特性に関するCASE Iと定常 表層流中における幕の設置効果に関するCASE IIの 2 通りを実施した。CASE IIでは表層流中に連行さ れる周囲水を補償する目的で、通水と同時に水槽下 部側面に設けられた多数の小孔を通じて若干の塩水 供給を行なった。この際、時間の経過にかかわらず、 表層流層厚が一定となるように塩水供給量を慎重に 調節した。

実験条件としては、CASE Iでは表層流の浮力-慣 性力領域、浮力-粘性力領域あるいは浮力-慣性力領 域が表れるように、水路の幾何学的条件 $\left(\mathrm{a} 、 \mathrm{~B}_{0}\right)$ と 流入条件 $\left(Q_{0} 、 \varepsilon_{0}\right)$ を様々に変化させた。ここに、 $\varepsilon_{0}$ は初期相対密度差 $\left(=\left(\rho_{\mathrm{a}}-\rho_{0}\right) / \rho_{\mathrm{a}}\right)$ である。その際、上 下層が明確な界面を有する表層流を実現するために、 流入水が流入部から水槽に流出した直後に生じる初 期混合が極めて小さくなるように流入条件を設定す る必要がある。予備実験結果によれば、この条件は 流入点での内部Froude 数 $\mathrm{F}_{0}\left(=\mathrm{Q}_{0} / \mathrm{B}_{0}\left(\varepsilon_{0} \mathrm{ga}^{3}\right)^{1 / 2}\right)<1.0$ を 満たす場合であった。ただし、 $\mathrm{F}_{0}$ が小さい方が界面 が安定することはあらためて言うまでもないが、過 剩に小さくすると流入直後の浮き上がりが顕著とな

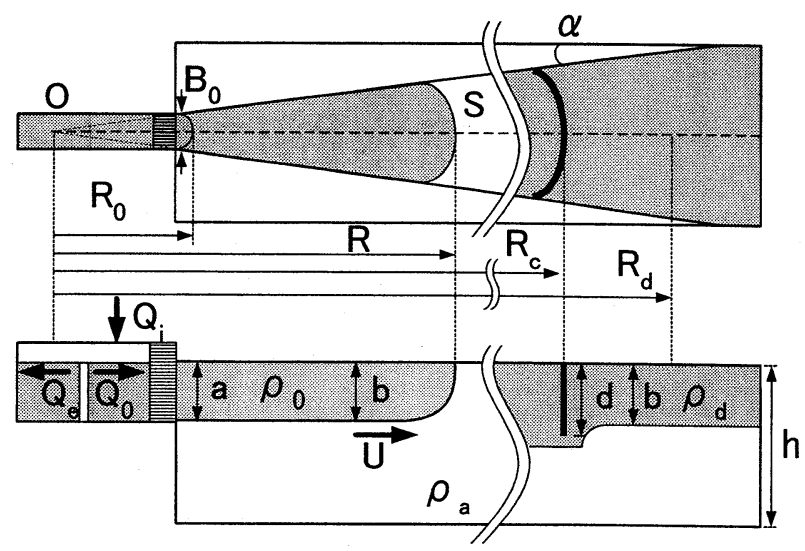

図-1 実験装置および流れの定義図 表-1 実験条件

\begin{tabular}{|c|c|c|c|c|c|c|c|c|}
\hline CASE I & $\begin{array}{r}\mathrm{h} \\
(\mathrm{cm}\end{array}$ & & $\left.{ }^{\alpha}\right)$ & $\begin{array}{c}\mathrm{a} \\
(\mathrm{cm})\end{array}$ & $\begin{array}{c}\mathrm{B}_{0} \\
(\mathrm{~cm})\end{array}$ & & $\varepsilon_{0}$ & $\begin{array}{c}Q_{0} \\
\left(\mathrm{~cm}^{3} / \mathrm{s}\right)\end{array}$ \\
\hline I $-1-1$ & \multirow{13}{*}{50} & \multirow{13}{*}{\multicolumn{2}{|c|}{1.24}} & \multirow{13}{*}{5} & 5 & \multicolumn{2}{|c|}{0.03} & 222 \\
\hline I $-1-2$ & & & & & 5 & \multicolumn{2}{|c|}{0.02} & 202 \\
\hline$I-2-1$ & & & & & 5 & \multicolumn{2}{|c|}{0.04} & 156 \\
\hline$I-2-2$ & & & & & 5 & \multicolumn{2}{|c|}{0.03} & 146 \\
\hline$I-3-1$ & & & & & 5 & \multicolumn{2}{|c|}{0.02} & 96.7 \\
\hline $\mathrm{I}-4-1$ & & & & & 5 & \multicolumn{2}{|c|}{0.01} & 59.8 \\
\hline$I-4-2$ & & & & & 5 & \multicolumn{2}{|c|}{0.0025} & 30 \\
\hline$I-5-1$ & & & & & 5 & \multicolumn{2}{|c|}{0.02} & 29 \\
\hline $\mathrm{I}-6-1$ & & & & & 5 & \multicolumn{2}{|c|}{0.01} & 10 \\
\hline$I-6-2$ & & & & & 5 & \multicolumn{2}{|c|}{0.01} & 9.9 \\
\hline$I-7-1$ & & & & & 2 & \multicolumn{2}{|c|}{0.05} & 124 \\
\hline$I-7-2$ & & & & & 0.7 & \multicolumn{2}{|c|}{0.05} & 45.5 \\
\hline I $-7-3$ & & & & & 0.7 & \multicolumn{2}{|c|}{0.1} & 68 \\
\hline CASE II & $\begin{array}{c}\mathrm{h} \\
(\mathrm{cm})\end{array}$ & $\begin{array}{c}a \\
(\mathrm{~cm})\end{array}$ & $\begin{array}{l}\mathrm{B}_{0} \\
(\mathrm{~cm})\end{array}$ & $\varepsilon_{0}$ & $\begin{array}{c}Q_{0} \\
\left(\mathrm{~cm}^{3} / \mathrm{s}\right)\end{array}$ & $\begin{array}{l}\mathrm{h}_{\mathrm{c}} \\
(\mathrm{cm})\end{array}$ & $\begin{array}{l}\mathrm{R}_{\mathrm{c}} \\
(\mathrm{cm})\end{array}$ & $\begin{array}{c}\mathrm{d} \\
(\mathrm{cm})\end{array}$ \\
\hline II $-1-1$ & \multirow{6}{*}{50} & \multirow{6}{*}{5} & \multirow{6}{*}{5} & \multirow{6}{*}{0.0045} & \multirow{6}{*}{100} & \multirow{6}{*}{4.5} & \multirow{3}{*}{225} & 0 \\
\hline II $-1-2$ & & & & & & & & 15 \\
\hline II $-1-3$ & & & & & & & & 25 \\
\hline II $-2-1$ & & & & & & & \multirow{3}{*}{265} & 0 \\
\hline II $-2-2$ & & & & & & & & 15 \\
\hline II $-2-3$ & & & & & & & & 25 \\
\hline
\end{tabular}

るので、ここでは $\mathrm{F}_{0}=0.06 〜 0.89$ 範囲で変化させ た。

一方、CASE IIではCASE Iの結果に基づき、全領 域にわたって浮力一慣性力領域が表れるように流入 条件を設定し、この流入条件を一定に保った状態で、 幕の設置深さd $/ h_{c}$ を 3.3 と 5.5 に変化させた。ここに、 $h_{c}$ は内部限界水深 $\left(=\left(\left(Q_{0} / B_{0}\right)^{2} / \varepsilon_{0} g\right)^{1 / 3}\right)$ である。また、 幕の設置位置を $\mathrm{R}_{\mathrm{c}} / \mathrm{B}_{0}=45$ と 53 に変化させた。ただし、 幕としてはアクリル板を用いた。このため、ここで は流体力等によるその変形については考慮されてい ない。実験条件をまとめて表-1に示す。

測定内容としては、CASE Iでは各流入条件につい て水路の中心軸に関する流れの対称性を確認した後 に、軸に沿ってスリット光を照射し、可視化した表 層流フロントの様子をCCDカメラで撮影し、デジタ 

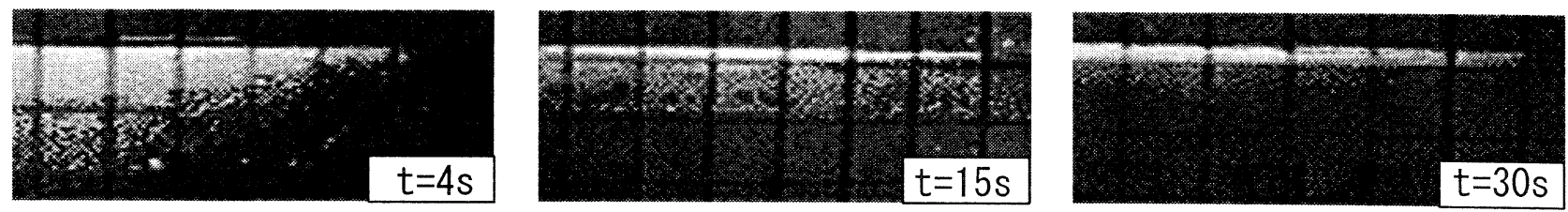

図-2 漸拡水路における表層流フロントの流動状況

ルVTRに収録された画像をコンピュータ解析するこ とにより、表層流のフロント形状とフロント侵入半 径Rを求めた。その際、同一条件下で複数回計測を 行い、测定結果の再現性を確認した。一方、CASE IIでは幕下端から流出した流入水が下層水と希釈混 合した後、再び安定した定常表層流を形成した地点 での鉛直塩分濃度分布を導電率計 (KENEK、MK-206) で測定した。その際、同一条件下で複数回計測を行 い、測定結果の再現性を確認した。

\section{3. 実験結果}

以下では、まず漸拡水路における表層流の流動特 性の定量化を行い、次に幕の設置による希釈混合効 果について検討を加える。

\section{(1) 漸拡水路における表層流フロントの流動特性}

図-2は、漸拡水路における表層流フロントの流動 状況の一例を示したものである。流入時には若干の 混合が認められるが、時間の経過とともに明瞭な界 面を有しながら表層流が周囲水表面に拡がって行く 様子がわかる。また、フロントの形状は時間の経過 とともに、流入直後のカルマンヘッド的な形状から 楔状に徐々に変化することが確認できる。

上下層が明確な界面を有し、水表面にせん断力が 働かない場合の軸対称表層流の無次元フロント侵入 半径R*は、浮力-慣性力領域では式 (1)、浮力-粘性 力領域では式 (2) でそれぞれ与えられる。一方、浮 力-慣性力領域と浮力-粘性力領域の無次元フロント 層厚b*は、それぞれ式(3) と式(4)で与えられる ${ }^{12)} 。$

$$
\begin{gathered}
\mathrm{R}_{1}^{*}=\frac{\mathrm{R}}{\left(\varepsilon_{0} g \mathrm{Q}_{0} \mathrm{t}_{1}^{3}\right)^{1 / 4}}=\mathrm{c}_{1}\left(\mathrm{t} / \mathrm{t}_{1}\right)^{3 / 4} \\
\mathrm{R}_{2}^{*}=\frac{\mathrm{R}}{\left(\varepsilon_{0} g \mathrm{Q}_{0}{ }^{2} / v^{1 / 2}\right)^{1 / 6} \mathrm{t}_{1}^{7 / 12}}=\mathrm{c}_{2}\left(\mathrm{t} / \mathrm{t}_{1}\right)^{7 / 12} \\
\mathrm{~b}_{1}^{*}=\frac{\mathrm{b}}{\left(\mathrm{Q}_{0} / \varepsilon_{0} \mathrm{~g}\right)^{1 / 2} \mathrm{t}_{1}^{-1 / 2}}=\mathrm{c}_{3}\left(\mathrm{t} / \mathrm{t}_{1}\right)^{-1 / 2} \\
\mathrm{~b}_{2}^{*}=\frac{\mathrm{b}}{\left(v^{1 / 2} \mathrm{Q}_{0} / \varepsilon_{0} \mathrm{~g}\right)^{1 / 3} \mathrm{t}_{1}^{-1 / 6}}=\mathrm{c}_{4}\left(\mathrm{t} / \mathrm{t}_{1}\right)^{-1 / 6}
\end{gathered}
$$

さらに、最も重要な流動特性量であるフロントの 内部Froude 数 $\mathrm{F}_{\mathrm{f}}\left(=\mathrm{U}^{3 / 2} \mathrm{~S}^{1 / 2} /\left(\varepsilon_{0} \mathrm{~g} \mathrm{Q}_{0}\right)^{1 / 2}\right)$ は、式 (1) と式 (2) を微分して得られるフロント移動速度Uとフロン 卜最先端の円弧長 $\mathrm{S}=\alpha \pi \mathrm{R} / 90$ を用いると、浮力一慣 性力領域と浮力一粘性力領域でそれぞれ式 (5) と式 (6)のように得られる。ここに、 $t_{1}$ 二両領域の遷移時 間 $\left(=\left(Q_{0} / \varepsilon_{0} g \nu\right)^{1 / 2}\right)$ である。

$$
\mathrm{F}_{\mathrm{f}}=\mathrm{c}_{5}
$$

$$
F_{f}=c_{6}\left(t / t_{1}\right)^{-1 / 3}
$$

これらの関係式は、フロントの局所的な特性量で はなく流入条件を用いた表示となっている点が特徴 であり利点であるが、各定数 $\mathrm{c}_{\mathrm{i}=1 \sim 6}$ の具体的な值が 全くわかっていないために、実際に適用することは できない。そこで以下ではこれらの定数值を明らか にする。

図-3と図-4は、それぞれ浮力一慣性力領域と浮力粘性力領域における流入点から測ったフロント侵入 半径 $\left(\mathrm{R}^{*}-\mathrm{R}_{0}{ }^{*}\right)$ とそこからの無次元経過時間 $\left(\mathrm{t}-\mathrm{t}_{0}\right) / \mathrm{t}_{1}$ との関係を示したものである。ここで、 $\mathrm{R}_{0}$ は仮想原 点0から流入点までの距離であり、ここでは $\mathrm{R}_{0}$ を流 入半径と呼ぶ。 $\mathrm{R}_{0}{ }^{*}$ は $\mathrm{R}_{0}{ }^{*}=\mathrm{R}_{0} /\left(\varepsilon_{0} \mathrm{gQ}_{0} \mathrm{t}_{1}{ }^{3}\right)^{1 / 4}$ で定義される 無次元流入半径である。これより、浮力一慣性力領 域では、経過時間が大きくなるにつれて式(1)の関 係に漸近する傾向が認められるが、全体的にはこの 関係に従っていないことがわかる。また、 $\mathrm{R}_{0}^{*}$ が大 きい方が式 (1) からのずれが大きいことも確認でき る。一方、浮力一慣性力領域においては式(1)の関係 に従わないデータも、浮力ー粘性力領域においては 経過時間が大きくなると、式 (2) の関係によく従う ことがわかる。このような傾向は、ここで取扱って いる表層流が厳密には軸対称流ではなく、図-1に示 す状況であることに起因していると考えられる。

図-1に示すような状況に対する上記の軸対称表層 流の関係式の妥当性を調べるためには、少なくとも フロントが仮想原点から流入点までの距離 $\mathrm{R}_{0} を$ 移動 するのに要する経過時間 $\mathrm{t}_{0}$ を知る必要がある。そこ でまず、実験装置の範囲内で $\mathrm{R}_{0}^{*}$ を可能な限り小さ く設定した疑似軸詨称流である $\mathrm{R}_{0}{ }^{*} \leqq 0.6$ のCASE I -7 の結果に基づき、 $c_{1}$ を算定した。図-5は、この場合 の $\mathrm{R}_{1}{ }^{*}$ と $\mathrm{t} / \mathrm{t}_{1}$ との関係を示したものである。これより、 $\mathrm{R}_{1}{ }^{*}$ はt $/ \mathrm{t}_{1}$ の3/4乗に比例しており、全域で軸対称流

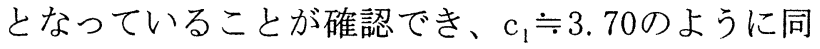
定される。 


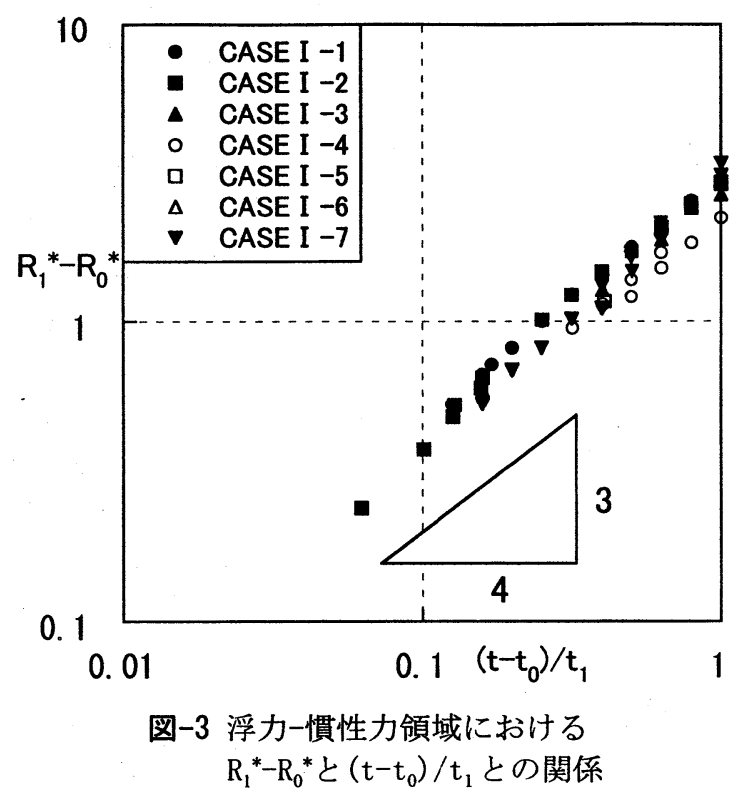

次に、この $\mathrm{c}_{1}$ の值と式(1)より、 $\mathrm{R}_{1}=\mathrm{R}_{0}$ となる $\mathrm{t}_{0}$ を 求め、この $\mathrm{t}_{0}$ を実験結果から得られた流入点からの 経過時間に加えることで、仮想原点からの経過時間 tを求めた。このようにして得られた各領域におけ る $\mathrm{R}^{*}$ と $\mathrm{t} / \mathrm{t}_{1}$ との関係を示したものが図-6である。こ れより、 $t / t_{1}=1.0$ 前後を境にして、 $\mathrm{R}^{*}$ の $\mathrm{t} / \mathrm{t}_{1}$ に対す る依存性が変化しており、浮力一慣性力領域では $\mathrm{t} / \mathrm{t}_{1}$ の $3 / 4$ 乗に、浮力-粘性力領域では $7 / 12$ 乗に比例 していることから、図-1に示寸状況であっても、上 記のような考慮をすることで、上下層が明確な界面 を有する場合の軸対称表層流の関係式がほぼ適用で きることがわかる。同図に基づき $\mathrm{c}_{2}$ を推定すると、 $\mathrm{c}_{2} \doteqdot 3.70$ が得られる。なお、既往の研究1) によれば、 漸拡水路での密度流は、 $\alpha \leqq 7^{\circ}$ であれば中心軸に 沿って軸対称であり、壁面での剥離も発生しないこ とがわかっている。従って、上記の関係式は、この 範囲の漸拡水路であれば上記の補正を施すことで適 用可能であると考えられる。ところで、図-3に示し たように、 $\mathrm{R}_{0}^{*}$ が十分小さければ軸対称流れとなる。 これは、 $\mathrm{R}_{0}{ }^{*}$ の定義から、 $\mathrm{R}_{0}$ が大きくても $\mathrm{Q}_{0}$ が十分に 大きければ、軸対称流れとなることを示している。 つまり、 $\mathrm{R}_{0}{ }^{*}$ が大きくても、無次元流入流量 $Q_{0}{ }^{*}\left(=Q_{0} /\left[R_{0}^{8 / 5}\left(\varepsilon_{0} g \nu^{3}\right)^{1 / 5}\right]\right)$ が十分に大きければ、軸対 称流れとなる。この傾向は図-3より確認できる。し かし、 $Q_{0}{ }^{*}=1 / \mathrm{R}_{0}^{*}{ }^{* 8 / 5}$ のような関係があるので、軸対称 流れとなるためには、 $\mathrm{Q}_{0}{ }^{*} よ り も \mathrm{R}_{0}{ }^{*}$ の影響の方がよ り強い。

以下の $\mathrm{b}^{*} と \mathrm{~F}_{\mathrm{f}}$ についても $\mathrm{t}_{0}$ に関する補正を $\mathrm{R}^{*}$ 同 様に行った。図一7は、各領域における $b^{*}$ と $t / t_{1}$ との 関係について調べたものである。図一2から明らかな ように、表層流フロントの形状は、底面に沿って流 動する重力密度流とは異なり、流入直後はカルマン ヘッド的な形状を呈するものの、その後は楔状に変 化する。このため、浮力ー慣性力領域では画像より ある程度代表的な層厚を判別することができるが、 浮力ー粘性力領域では完全な楔状に変化するため、 代表的なフロント層厚は存在しない。そこで、ここ

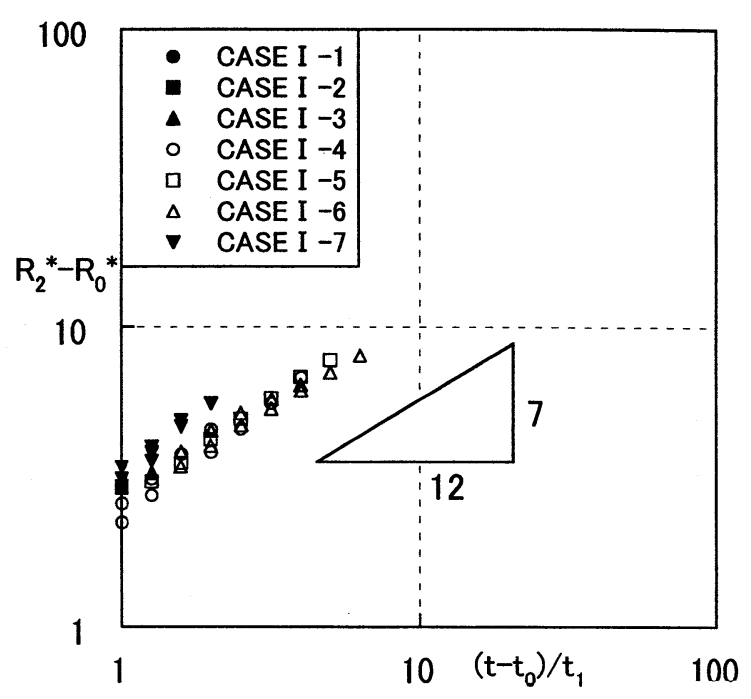

図-4 浮力-粘性力領域における $\mathrm{R}_{1}{ }^{*}-\mathrm{R}_{0}{ }^{*}$ と $\left(\mathrm{t}-\mathrm{t}_{0}\right) / \mathrm{t}_{1}$ との関係

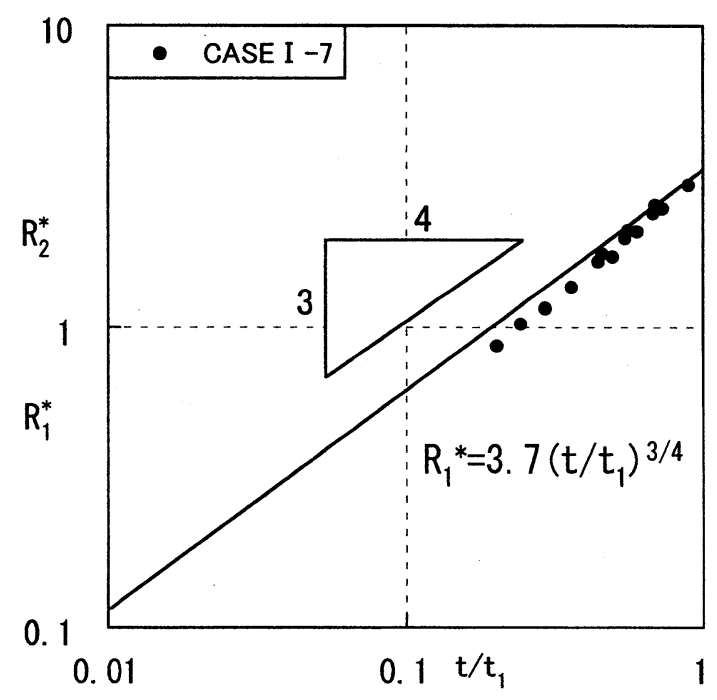

図-5 $\mathrm{R}_{0}^{*}<0.6$ の場合の $\mathrm{R}_{1}{ }^{*}$ と $\mathrm{t} / \mathrm{t}_{1}$ との関係

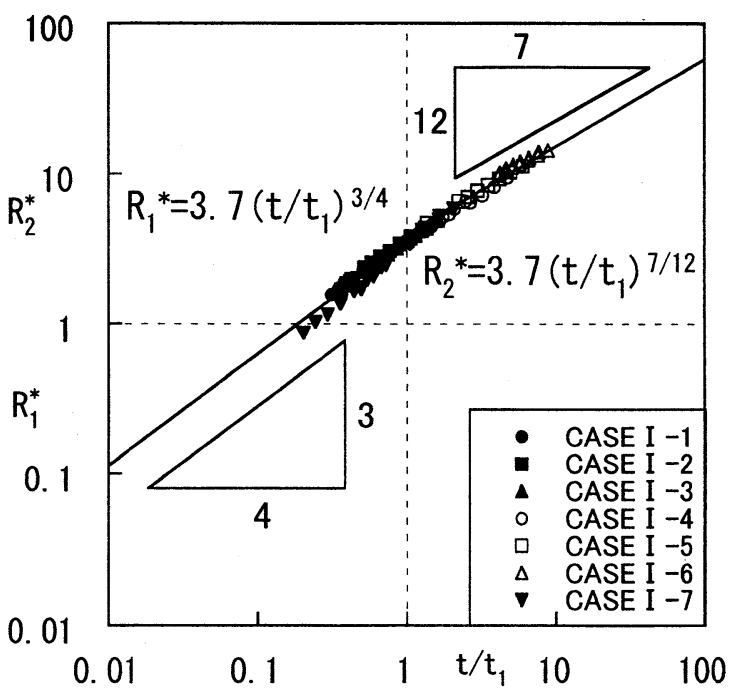

図-6 各領域における $R^{*}$ と $t / t$, との関係 


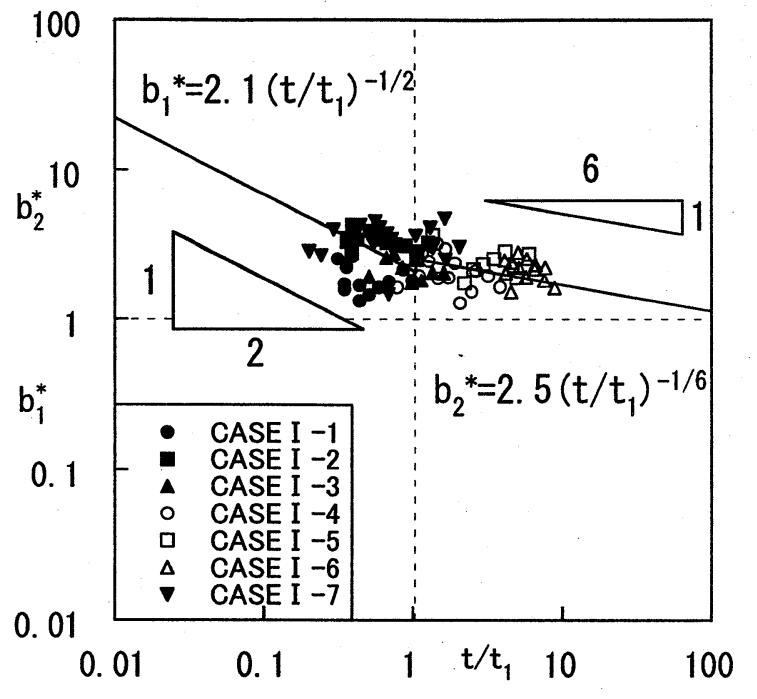

図-7 各領域における $b^{*}$ と $t / t_{1}$ との関係

では0.95Rの位置での層厚をもってbと定義した。こ

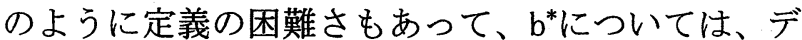
一タのばらつきが認められるが、ほぼ各領域で式 (3) と式 (4)の関係に従っていることがわかる。同図 に基づき定数值 $\mathrm{c}_{3}$ と $\mathrm{c}_{4}$ を推定すると、それぞれ $\mathrm{c}_{3} \fallingdotseq 2.1$ および $\mathrm{c}_{4} \fallingdotseq 2.5$ のようになる。

図-8は、各領域における $\mathrm{F}_{\mathrm{f}}$ と $\mathrm{t} / \mathrm{t}$, との関係を示した ものであり、各領域でほぼ式(5) と式(6)の関係に従 っていることがわかる。同図に基づき定数值 $\mathrm{c}_{3}$ と $\mathrm{c}_{4}$ を

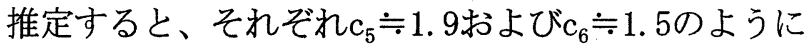
なる。以上の結果をまとめると表-2のようになる。 ここで、 $c_{5}$ と $c_{6}$ にはそれぞれ $c_{5}=(\alpha \pi / 90)^{1 / 2}(3 / 4)^{3 / 2} c_{1}{ }^{2}$ と $c_{6}=(\alpha \pi / 90)^{1 / 2}(7 / 12)^{3 / 2} c_{2}{ }^{2}$ なる関係がある。これらの式 に基づくと、 $\mathrm{c}_{5}=1.8$ およ゙ $\mathrm{c}_{6}=1.2$ となり、上記の図 -8 から得られる倸数值とおおよそ一致する。

\section{(2) 漸拡水路におけるフェンスエの設置効果}

図-9は、フェンス工まわりの流動状況が、幕の無 次元設置深さd/h $/ h_{c}$ にって変化する様子を示したも のである。これより、フェンスエの設置によって幕 の上流側に貯留された表層水が幕下端から流出する ことで希䆏され、表層流の層厚が増加することがわ かる。目視観測によると、幕の下端より流出した表 層流体が幕の背面に沿って浮力効果により上昇する 際に発生する渦によって、周囲流体が取込まれリフ トアップすることで表層流の希釈が生じることが認 められた。

図-10 と図-11は、幕の下流の再度安定した表層流 が形成される地点での相対密度分布を示したもので ある。なお、yは水表面から測った距離であり、図 中の分布は再度安定した表層流の層厚 $\mathrm{b}$ と初期相対 密度差 $\varepsilon_{0}$ で正規化されている。また、bの定義はそ こでの相対密度差が 0 となる水深としている。同図 より、無次元設置深さd $/ \mathrm{h}_{\mathrm{c}}$ か増加すると表層の希釈 が促進されることがわかる。ここで、 $\varepsilon_{\mathrm{d}}$ は幕下流で の相対密度差 $\left(=\left(\rho_{\mathrm{a}}-\rho_{\mathrm{d}}\right) / \rho_{\mathrm{a}}\right)$ である。

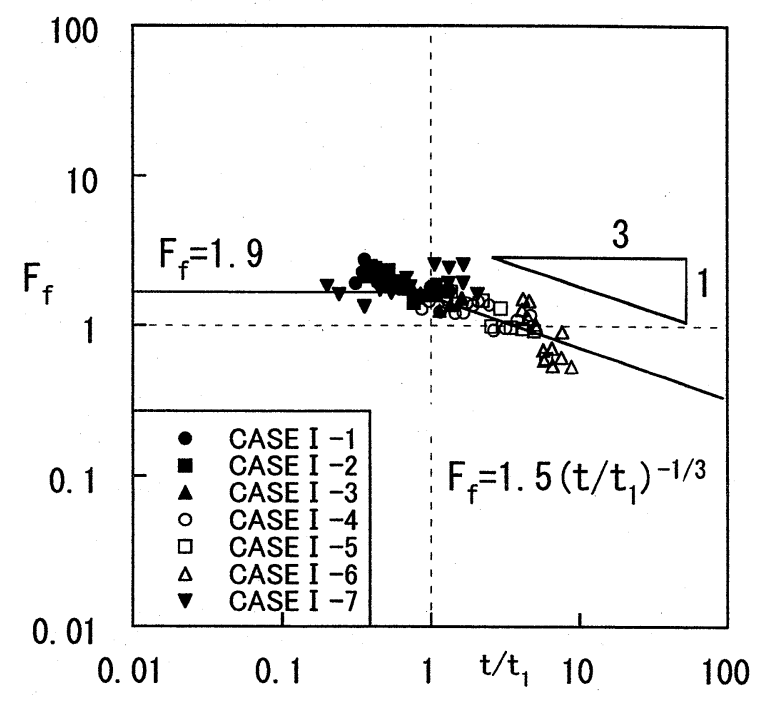

図-8 各領域における $F_{f}$ と $t / t_{1}$ との関係

表-2 漸拡水路における表層流の流動特性

\begin{tabular}{|c|c|c|}
\hline & $\begin{array}{c}\text { 浮力-慣性力領域 } \\
\mathrm{t}<\mathrm{t}_{1}\end{array}$ & $\begin{array}{c}\text { 浮力-粘性力領域 } \\
\mathrm{t}>\mathrm{t}_{1}\end{array}$ \\
\hline $\mathrm{R}^{*}$ & $\mathrm{c}_{1} \fallingdotseq 3.7$ & $\mathrm{c}_{2} \fallingdotseq 3.7$ \\
\hline $\mathrm{b}^{*}$ & $\mathrm{c}_{3} \fallingdotseq 2.1$ & $\mathrm{c}_{4} \fallingdotseq 2.5$ \\
\hline $\mathrm{F}_{\mathrm{f}}$ & $\mathrm{c}_{5} \fallingdotseq 1.9$ & $\mathrm{c}_{6} \fallingdotseq 1.5$ \\
\hline
\end{tabular}

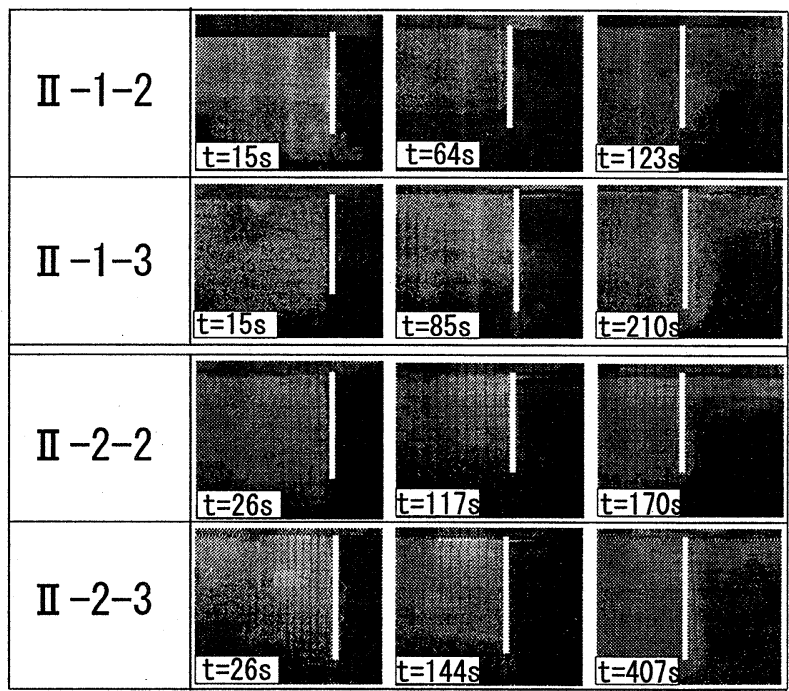

図-9 フェンスエまわりでの流動状況の一例

図-12は、幕の設置に伴う流入水の混合率 $\gamma\left(=Q_{\mathrm{m}} / Q_{0}\right)$ と無次元設置深さ $d / h_{c}$ との関係について調べたもの である。ここで、 $Q_{\mathrm{m}}$ は幕の設置に伴う総連行量、 $\gamma$ は幕の設置に伴う正味の混合率であり、浮カフラッ クスの保存に基づき、 $\gamma=-1+\varepsilon_{0} / \varepsilon_{\mathrm{d}}{ }^{*}-\gamma_{0}$ より算定し た。ここに、添字＊は層平均量であることを示し、 $\gamma_{0}$ は幕が設置されていない状態での流入点から測 定位置までの総連行率であり、その值は約 0.43 であ. った。同図より、 $\gamma$ 值に設置位置による若干の違い 


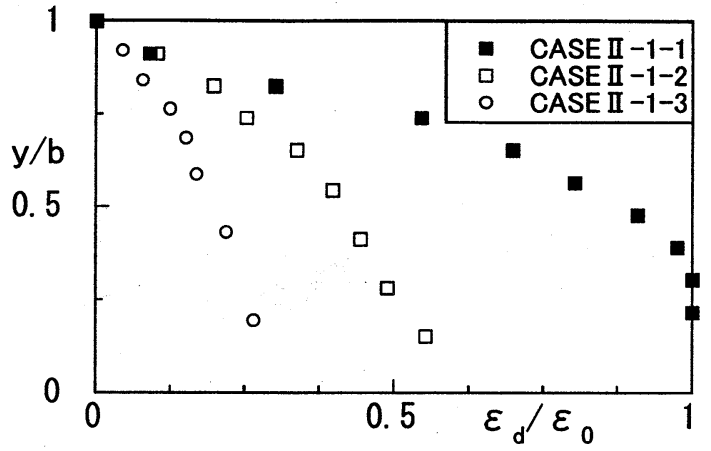

図-10 CASE II -1 における幕下流での 定常表層流の相対密度分布

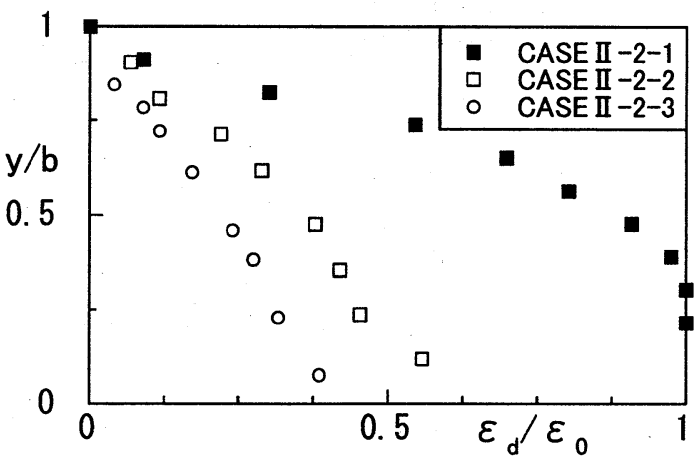

図-11 CASE II -2 における幕下流での 定常表層流の相対密度分布

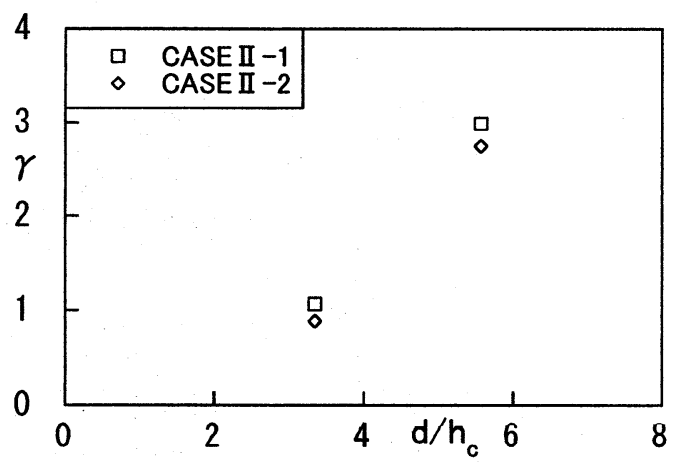

図-12 混合率 $\gamma$ と無次元設置深さ $d / h_{c}$ との関係

が認められるが、これは界面を通じての混合の違い であると考えられる。 $\gamma$ はd $/ \mathrm{h}_{\mathrm{c}}$ の増加とともに急激 に大きくなり、 $\mathrm{d} / \mathrm{h}_{\mathrm{c}} \fallingdotseq 3$ で $100 \%$ の希釈混合効果が期 待できることから、この程度の設置深さにすれば、 フェンスエの設置によって密度差を半分に減少させ ることがわかる。

以上より、幕の下流側では流入水の密度が減少す るため、表層流を中層流へ転化できる可能性があり、 栄養塩類の流入と光合成反応に必要な光や水温など の環境条件の制御や操作が可能であると考えられる。

\section{4. まとめ}

本研究によって次のような結論が得られた。

（1）上下層が明確な界面を有する時の漸拡水路に おける浮力一慣性力領域および水表面にせん断力が 働かない場合の浮力一粘性力領域における表層流フ
ロントの流動特性を明らかにした。

（2）定常表層流中に設置された幕による希釈混合 効果について検討を加えた結果、(1)表層流中に幕を 設置することで、下層の重い流体との希釈混合効果 が期待でき、 $\mathrm{d} / \mathrm{h}_{\mathrm{c}} \fallingdotseq 3$ で $100 \%$ の希釈混合効果が期待 できること、(2)跳層が存在しない混合型貯水池では 設置深さの基準が全くないが、そのような場合は流 入条件との関係で希釈率が規定されるため、図-12 が一つの目安になること、などの知見が得られた。

\section{参考文献}

1) 秋山壽一郎：流入型密度流の水理特性とその予測, 湖沼・貯水地の管理に向けた富栄養化現象に関する 学術研究のとりまとめ, 土木学会水理委員会環境水 理部会, pp.69-167, 2000.

2) 吉村 佐、田島良一、斉藤暁樹、井芹 寧 : 寺内ダ 么貯水池における水質管理の調査報告, ‘ダム技術,

No.114, pp.35-46, 1996.

3) Priyantha, D.G.N. et al.: Modelling the effects of curtains on water quality of eutrophic reservoir, Annual J. of Hydraulic Engineering, Vol.40, pp.7-12, 1996.

4) 椿東一郎、小松利光 : 2 次元表面密度噴流における 流れの特性と連行現象，土木学会論文集，第 273 号, pp.69-81, 1978.

5) 中辻啓二、許 再寧、室田 明：河川プルームの拡 がり特性とその物理機構, 土木学会論文集, No.434/II-16, pp.29-36, 1991.

6) 和田 明、片野尚明： 3 次元数値モデルによる排水 プルームの挙動解析, 電力中央研究所報 3708031 , 1983.

7) Rodi, W.: Turbulence models and their applications in hydraulics, State of the Arts Paper, IAHR, 1980.

8) Jirka, G.H. et al.: Buoyant surface jets, J. of Hydraulics Division, ASCE, Vol.107, No.11.pp.1467-1488, 1981.

9) List, E.J.: Turbulent jets and plumes, Ann. Rev. of Fluid Mechanics, Vol.14, pp.189-212, 1982.

10) Hoult, D.P.: Oil spreading on the sea, Ann. Rev. of Fluid Mechanics, Vol.4, pp.341-368, 1972.

11）羽田野袈裟義、天野卓三、松本治彦、埜口英昭、平 野宗夫 : 水表面の油層の 1 次元的な拡がりについて, 土木学会論文集, No.593/II-43, pp.117-124, 1998.

12) Didden, N. and Maxworthy, T.: The viscous spreading of plane and axisymmetric gravity current, J. of Fluid Mechanics, Vol.121, pp.27-42, 1981.

13）秋山壽一郎、アキレスクマールジャ、山崎 勉、浦 勝 : 表層流の流動特性と遮蔽幕による希釈混合効果, 水工学論文集, 第46巻, pp.1025-1030, 2001.

14) Kao, T.W.: Density currents and their applications, $J$. of the Hydraulics Division, ASCE, Vol.103, HY.5, pp.543556, 1977.

15) Huppert, H.E. \& Simpson, J.E.: The slumping of gravity current, J. of Fluid Mechanics, Vol.99, pp.785-799, 1980.

(2002. 9. 30受付) 